\title{
Characteristic Curves of Iridium-Rhodium Sensing Elements in High- Temperature Transducer Applications
}

\author{
Vasyl Fedynets ${ }^{*}$, Yaroslav Yusyk, Ihor Vasylkivskyi \\ Lviv Polytechnic National University, 12 S. Bandera St., Lviv, 79013, Ukraine
}

Received: April 04, 2021. Revised: May 17, 2021. Accepted: May 24, 2021.

(c) 2021 The Authors. Published by Lviv Polytechnic National University.

\begin{abstract}
In order to increase the capacity and efficiency factor of gas turbines and internal combustion engines while preserving their high reliability, the gas temperature and its distribution need to be measured in combustion chambers. Values of these temperatures can exceed $1800^{\circ} \mathrm{C}$ in an oxidizing atmosphere. Therefore, designing temperature transducers for measurements in such severe environments, special attention should be paid to the selection of thermometric materials. The requirements of the necessary accuracy and temperature range over $1800^{\circ} \mathrm{C}$ in an oxidizing atmosphere are fulfilled only by the temperature transducer based on iridium-rhodium alloys. The characteristic curve of such sensing elements is individual and each temperature transducer is to be calibrated. The paper discusses a technique of determining the individual characteristic curve of iridium-rhodium sensing elements of high-temperature transducers. The preparation steps to be taken prior to the calibration and the main stages of determining the characteristic curve are described. The general view of the experimental set for calibrating the sensing elements is presented. Based on the calibration results, the form of approximating polynomial of the individual characteristic curve is proposed.
\end{abstract}

Keywords: temperature; characteristic curve; calibration; iridium-rhodium sensing elements.

\section{Definition of the research problem selected for the study}

To raise the single-unit capacity and efficiency factor of aviation and industrial gas turbines and internal combustion engines, it is necessary to increase the gas temperature and pressure in their combustion chambers. Raising the temperature necessitates studies associated with measuring the gas temperature distribution in the combustion chambers in order to achieve the desired reliability. Under the conditions of these measurements, the temperature transducer (TT) is subjected to a strong influence of high temperatures (up to $2200{ }^{\circ} \mathrm{C}$ ) in an oxidizing atmosphere. Such temperature measurement conditions are rather severe. Therefore, the choice of thermometric and construction materials should be paid special attention to, when creating TT designs.

\section{Analysis of the recent publications and studies of the issue}

The choice of construction heat-insulating materials for high TT is defined by such properties of these materials as the high-temperature resistance in the measurement environment, thermal stability, gas tightness, heat capacity, thermal conductivity, coefficient of linear thermal expansion, processibility, chemical compatibility with the thermometric materials and materials of the sheath, impurities affecting the main properties. The results of studying thermal and electrical insulators for high TT are presented in [1].

${ }^{*}$ Corresponding author. Email address: vasyl.o.fedynets@1pnu.ua

This paper should be cited as: V. Fedynets, Y. Yusyk, I. Vasylkivskyi. Characteristic curves of iridium-rhodium sensing elements in high-temperature transducer applications. Energy Engineering and Control Systems, 2021, Vol. 7 , No. 1, pp. 62 - 67. https://doi.org/10.23939/jeecs2021.01.062 
Of the slowly oxidizing thermometric materials, iridium has the highest melting point. This makes it possible to make thermocouples for measuring temperatures up to $2200^{\circ} \mathrm{C}$ in oxidizing atmospheres typical for the hydrocarbon fuel post-combustion flow.

The requirements of the desired accuracy and temperature range in an oxidizing atmosphere are satisfied only by using the thermocouple with the positive wires of iridium+60\% rhodium (IR60) and negative wires of iridium (Ir) [2], [3]. The characteristic curve is denoted by IR60/0. In foreign literature there are also iridium-rhodium thermocouples with the characteristic curve IR60/40 with positive wires of iridium+60\%rhodium (IR60) and negative wires of iridium+40\%rhodium (IR40) [4]. Thermocouples made of iridium-rhodium alloys are the only ones that can sustain long-term use in harsh oxidizing conditions under high temperatures $\left(1800 \ldots 2200^{\circ} \mathrm{C}\right)$.

\section{Aim of the research}

The study aims at developing the theoretical and practical basis for using iridium-rhodium sensing elements of high-temperature transducers and a system of engineering tools for testing their metrological characteristics and calibration.

The said aim is to be achieved through pursuing such research objectives as substantiating the practicability of using a TIP-0182 thermoelectric iridium-rhodium temperature transducer for measuring the temperature of the hydrocarbon fuel combustion products when testing the instruments on the test stands, developing a technique for determining the individual characteristic curve for the iridium-rhodium sensing elements, proposing a design of a set for calibrating the iridium-rhodium sensing elements, coming up with the form of approximating polynomial of the individual characteristic curve.

\section{Results and their discussion}

A typical thermoelectric temperature transducer with iridium-rhodium thermocouple wires is TIP-0182 for measuring the temperature of hydrocarbon fuel combustion products when testing the instruments on the test stands. The general arrangement of the two designs of the temperature transducer with longitudinal flow is presented in Fig. 1, 2 .

The main technical characteristics of TT are as follows:

- the temperature measurement range is from 650 to $2100^{\circ} \mathrm{C}$;

- the permissible value of the intrinsic error does not exceed $\pm 1.5 \%$ of the measured temperature;

- the thermal response time does not exceed $2 \mathrm{~s}$;

- the recovery factor is $0.96 \ldots 0.98$ for the Mach number $M$ in the retardation chamber from 0.2 to 0.6 ;

- the number of heating, holding and cooling cycles in the temperature range from 20 to $2100^{\circ} \mathrm{C}$ is no less than 15 for the total operation time of 25 hours.

In design 1 (TIP-0182, Fig. 1), the retardation chamber is made by molding with further heat treatment with silicon carbide powder. The two outlets of the retardation chamber are $2 \mathrm{~mm}$ in diameter and are located past the hot end. The diameter of the outlets is designed so as to ensure gas flow retardation and provide conditions for achieving a constant recovery factor. The ratio of the areas of the inlets $F$ to the areas of the outlets $n f$, through which the gas flow enters the retardation chamber and leaves it, $n f / F=0.125$. The sheath measures $5 \times 1 \mathrm{~mm}$. The thermocouple wires are insulated by two-way beryllium oxide tubes. The insulated thermocouple wires and insulator in the sheath are fixed with thermal cement F50. The TT is welded to the housing of the measurement probe.

In design 2 (TIP-0182-01, Fig. 2), each thermocouple wire is insulated by the one-way beryllium oxide tube and is placed in the sheath. The resulting structure has a slot running along the housing, which functions as the TT retardation chamber. The ratio $n f / F=0.135$. TT is fixed by fitting it onto the thermal probe. TT is held on the thermal probe by friction.

Temperature transducers TIP-0182 were developed for measuring temperatures up to $2100^{\circ} \mathrm{C}$ in an oxidizing environment. They are successfully used for studying new instruments on test stands. 


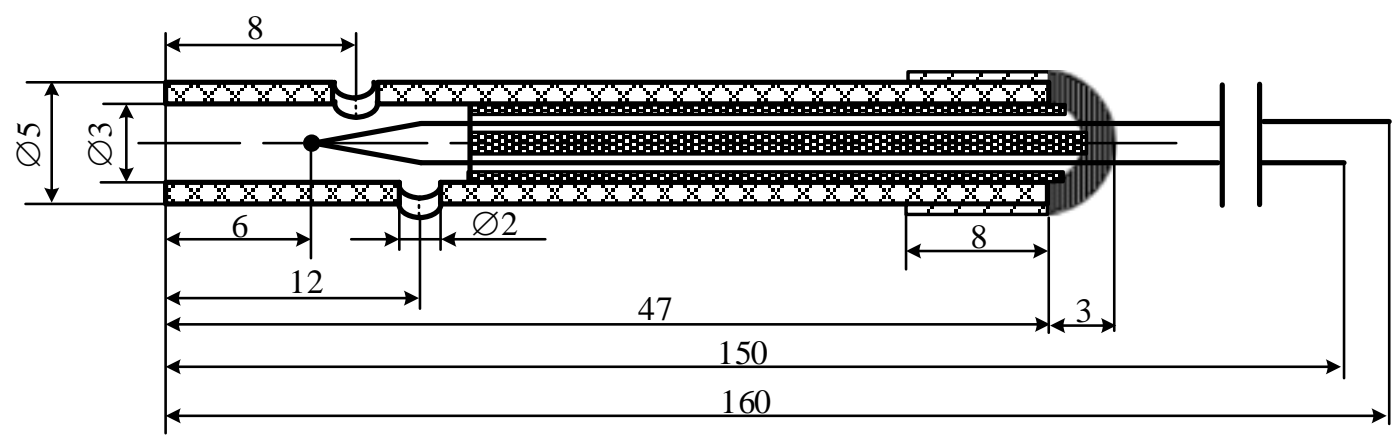

Fig. 1. The general arrangement of TIP-0182 temperature transducer: 1 - retardation chamber; 2 - thermocouple end; 3 -insulating tube; 4 - metal bushing; 5 - thermal cement F50; 6- protection housing

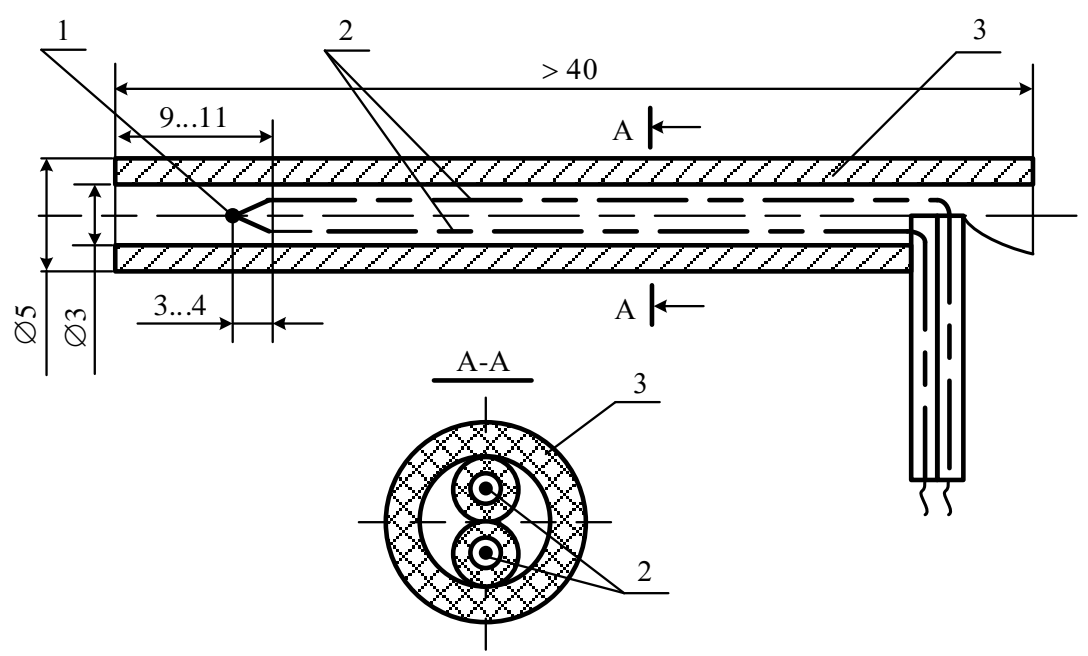

Fig. 2. The general arrangement of TIP-0182-01 temperature transducer: 1 - hot end; 2 - thermocouple wires insulated by one-way tube; 3 - insulating tube

The characteristic curve of converting the sensing elements is individual (IR60/0) and each thermocouple $i$ is to be calibrated, which consists in assigning certain graduation lines the corresponding values of the parameter being measured.

\subsection{Calibration technique}

Prior to calibration, it is necessary to carry out a visual examination so as to ensure that the general views of TT and thermocouple sensing elements comply with the requirements set in the operation guidelines, to test the continuity of the sensing element circuit using an ohmmeter for measuring the electrical resistance with the error not exceeding $\pm 1.5 \%$ and to check the electrical resistance of the TT insulation with a megohmmeter with the nominal voltage of $500 \mathrm{~V}$ and measurement range from 0.1 to $500 \mathrm{MOhm}$ with the error below $\pm 10 \%$.

The calibration was performed by comparing with the standard TT on the reels of thermocouple wire material of iridium (Ir) 99.8 and iridium/rhodium alloy 60 (IR), each of which, before making the sensing elements, is a segment of wire no less than $5 \mathrm{~m}$ long. The standard TT was the standard of properties of thermocouple wire materials made of the alloys [wolfram $+5 \%$ rodium] (the positive wire) and [wolfram $+20 \%$ rodium] (the negative wire). The nominal characteristic curve of the standard is BP 5/20 (A) according to the state standard of Ukraine [5] and EU standard [6].

Throughout the calibration, the following conditions were maintained: the ambient temperature $(20 \pm 5){ }^{\circ} \mathrm{C}$; relative humidity of the environment $(60 \pm 20) \%$; air pressure from 84 to $106 \mathrm{kPa}$; absence of vibrations and magnetic fields. 


\subsection{Preparation for calibration}

The calibration was preceded by the following preparation steps:

- checking the availability of the instrument certificates, certification and examination documents for all the calibration tools issued by metrological facilities, manufacturer's certificates for the thermocouple wire of iridium and iridium/rhodium alloy;

- pieces of wire no less than $80 \mathrm{~cm}$ long were cut from the beginning and the end of the thermocouple wire reel and two thermocouples were made;

- to obtain the hot ends (of the sensing element), the ends of each thermocouple were welded together in argon atmosphere; each couple and standard TT were fitted with two-way insulators of beryllium oxide;

- the obtained sensing element and standard TT were placed in the furnace in such a way so that their hot ends were located in the zone of the minimum temperature gradient;

- the free ends of the sensing element and standard TT were thermostated at $0^{\circ} \mathrm{C}$ and using extension wires were connected to the potentiometer set keeping the polarity (or to a digital millivolt meter using a switch). The standard TT was connected to the input $\mathrm{X}_{1}$, and the sensing element to the input $\mathrm{X}_{2}$. The experimental setup for calibrating the iridium-rhodium sensing elements consisted of the following parts: electrical furnace with the control unit; iridium-rhodium/ iridium sensing elements to be calibrated; sample TT; potentiometer; argon cylinder.

- the potentiometer set (or digital millivolt meter) was switched on and the function was checked according to the specification and manual;

- the furnace was vacuumed to the value no more than $0.01 \mathrm{kPa}$ and argon was fed in the operating space of the furnace under the positive pressure of $20 \ldots 30 \mathrm{kPa}$. The furnace was turned on and the desired mode of electricity supply was set up.

It should be noted that throughout the preparatory stage and calibration, the appertaining safety measures should be implemented.

\subsection{Determination of the individual characteristic curve}

The characteristic curve was determined in the temperature range from 600 to $2100^{\circ} \mathrm{C}$ at temperature points of 600,1200 and $2100^{\circ} \mathrm{C}$. The permissible tolerance of the temperature did not exceed $\pm 50^{\circ} \mathrm{C}$. To ensure that, the furnace heating mode was set up so that the heating speed did not to exceed $50^{\circ} \mathrm{C} / \mathrm{min}$.

When measuring the thermal electromotive force in each temperature point, the speed of temperature change did not exceed $1 \ldots 1.5^{\circ} \mathrm{C} / \mathrm{min}$ [7]. The measurements started with the standard TT and ended with the last sensing element to be calibrated. After that, all the measurements were repeated in the reverse order and so on until four readings in each row were obtained. The time intervals between the readings of the thermal electromotive force within the whole measurement cycle were approximately equal and did not exceed $30 \mathrm{~s}$.

Then the furnace temperature was increased up to the next calibration point, and all the operations presented above were repeated until the end of calibration.

Based on the results of calibrating the two sensing elements, the mean value of the thermal electromotive force $E_{t i}$ at the calibration temperature is

$$
\bar{E}_{t i}=\frac{E_{t i}^{n}+E_{t i}^{\kappa}}{2},
$$

which is then reduced to the temperatures 600,1200 and $2100^{\circ} \mathrm{C}$ using the expression:

$$
E_{t n i}=\bar{E}_{t i}+\left(\frac{d E}{d t}\right)_{t n i} \cdot \Delta t,
$$


where $E_{t i}^{n}, E_{\mathrm{ti}}^{\kappa}$ are the thermal electromotive forces of the thermocouples made from the beginning and the end of the thermocouple wire reels at the calibration temperature $t_{i} ; E_{t i n}$ is the thermal electromotive force of the thermocouple, reduced to the temperature $t_{n i}\left(t_{n i}=600 ; 1200\right.$ and $\left.2100^{\circ} \mathrm{C}\right) ; \Delta t=t_{n i}-t_{i} ;(d E / d t)_{t n i}$ is the mean response of the thermocouples at temperatures $t_{n i}$.

The value of $E_{t n i}$ was recorded in the report.

\subsection{The algorithm of calculating the individual characteristic curve}

The error of measuring the temperature of high TT depends on the dispersion of the values of the characteristic curves and their stability. The accurate determination of the characteristic curve using mathematical tools based on several point of the operating range makes it possible to reduce significantly the spread of characteristic curves for a certain class of TT and to increase the accuracy of measuring the temperature of the object under study.

The individual temperature dependences obtained according to the above-presented technique were described using the approximating polynomial:

$$
E_{t}=\sum_{i=1}^{n} C_{i} \cdot t^{i}
$$

where $E_{t}$ is the value of the thermal electromotive force of the sensing element in $m V$ for the temperature $t$ measured in ${ }^{\circ} \mathrm{C} ; C_{i}$ are the polynomial coefficients; $i=1,2, \ldots, n ; n$ is the degree of the approximating polynomial.

The task consists in finding the best approximating polynomial $E_{t}$. The coefficients $C_{i}$ that define the best approximating polynomial are calculated using the least-squares method [8].

As a result of the above-presented study, the characteristic curve of iridium-rhodium sensing elements was determined as the polynomial

$$
E_{t}=E_{600}+A(t-600)+B(t-600)^{2}
$$

where $E_{600}$ is the value of the thermal electromotive force for the temperature $600^{\circ} \mathrm{C}, \mathrm{mV} ; \mathrm{A}=0.016339 \mathrm{mV} / \mathrm{C}$; $\mathrm{B}=-0.00000376 \mathrm{mV} / \mathrm{C}^{2}$.

The obtained individual characteristic curve applies only to the reels of the thermocouple wire of which the sensing elements for the calibration were made. We also noted the poor ductility properties of the thermocouple wire materials, which complicates making thermocouples.

\section{Conclusion}

1. The typical design of the temperature transducer with the iridium-rhodium sensing element for temperature measurements above $1800^{\circ} \mathrm{C}$ in oxidizing environments was presented.

2. A technique for determining the individual characteristic curve of the iridium-rhodium sensing elements was developed.

3. The preparation steps preceding the calibration were described.

4. A calibration set design for the iridium-rhodium sensing elements was proposed.

5. Based on the calibration results, the form of the best approximating polynomial for the individual characteristic curve of the iridium-rhodium sensing elements was proposed.

6. The use of such thermocouples is viable only in vacuum and oxidizing environments, as in reducing environments they rapidly change their thermoelectric properties.

\section{References}

[1] Fedynets, V.O. Study of heat and electrical insulating materials for gas flow temperature measurement tools [Text] / V.O. Fedynets // Scientific Bulletin of UNFU. - 2011. - Vol. 21.1. - pp. 126 - 130. (in Ukrainian)

[2] Temperature measurement: theory and practice [Text] / [Lutsyk, Ya.T., Huk, O.P., Lakh, O.I., Stadnyk, B.I.]. - Lviv.: Beskyd Bit Publishers, 2006. -560 p. (in Ukrainian) 
[3] Stadnyk, B. Thermoelectric materials science and nanotechnology. Practice and theory [Text] / B. Stadnyk, S. Yatsyshyn, Ya. Lutsyk, T. Burbela, T. Frohlich / Measuring Equipment and Metrology. Vol. 80, No. 2, 2019. - pp. 30-40. DOI: https://doi.org/10.23939/istcmtm2019.02.030 (in Ukrainian)

[4] Lieneweg, F. Temperature measurement in engineering. Handbook. Translated from German. [Text] - M.:Metallurgia, 1980. - 544 p. (in Russian)

[5] Thermoelectric temperature transducers. Part 1. Performance specification and tolerance of the electromotive force (EMF): DSTU EN 60584-1:2016 (EN 60584-1:2013, Idt). - [Effective 2016-11-01]. - Kyiv: State Committee of Ukraine for Technical Regulation and Consumer Policy, 2016. - 90 p. - (National Standards of Ukraine). (in Ukrainian)

[6] IEC 60584-1:2013. Thermocouples - Part 1: EMF specifications and tolerance.

[7] Fedynets, V.O. Calculation of optimal modes of calibration of high-temperature transducers [Text] / V.O. Fedynets // Scientific Bulletin of UNFU. - 2007. - Vol. 17.2. - pp. 92 - 97. (in Ukrainian)

[8] Numerical methods: tutorial [Text] / [V.M. Zadachin, I.H. Koniushenko]. - Kh.: Simon Kuznets Kharkiv National University of Economics Publishers, 2014. - 180 p. (in Ukrainian)

\title{
Визначення статичної характеристики іридійродісвих чутливих елементів високотемпературних термоперетворювачів
}

\author{
Василь Фединець, Ярослав Юсик, Ігор Васильківський
}

Національний університет "Львівська політехніка", вул. Степана Бандери, 12, Львів, 79013, Україна

\section{Анотація}

Для підвищення потужності і коефіцієнта корисної дії газових турбін і двигунів внутрішнього згоряння при забезпеченні їх високої надійності необхідно вимірювати температуру газів та ії розподіл в камерах згоряння. Значення цих температур можуть перевищувати $1800{ }^{\circ} \mathrm{C}$ в окислювальному середовищі. Тому при створенні конструкцій термоперетворювачів для вимірювання в таких складних умовах особливу увагу необхідно звернути на вибір термометричних матеріалів. Вимогам необхідної точності і температурного діапазону вище $1800{ }^{\circ} \mathrm{C}$ в окислювальному середовищі задовільняє тільки термоперетворювач 3 термоелектродами на основі іридію та іридійродієвих стопів. Статична характеристика перетворення таких чутливих елементів $є$ індивідуальною і кожен термоперетворювач підлягає градуюванню. Розглянуто методику визначення індивідуальної статичної характеристики перетворення іридійродієвих чутливих елементів високотемпературних термоперетворювачів. Описано підготовчі роботи, які необхідно виконати до проведення градуювання та основні етапи визначення статичної характеристики. Наведено загальний вигляд експериментальної устави для градуювання чутливих елементів. За результатами градуювання запропоновано форму апроксимаційного полінома індивідуальної статичної характеристики.

Ключові слова: температура; статична характеристика; градуювання; іридійродієві чутливі елементи. 